\title{
New records of marine "sea slugs" (Mollusca: Gastropoda: Heterobranchia) in the outlets of the estuary systems in Paraná, southern Brazil
}

\author{
Augusto Ferreira-Jrit ${ }^{1 *}$ Iarema Carvalho $^{2}$, Susete Christo ${ }^{3}$ and Theresinha Absher ${ }^{1}$ \\ 1 Universidade Federal do Paraná, Centro de Estudos do Mar, Laboratório de Moluscos Marinhos. CEP 83255-976, Pontal do Paraná, PR, Brazil \\ 2 Mestranda do Programa de Pós Graduação em Oceanografia Física, Química e Geológica da Universidade Federal do Rio Grande. CEP 96201-900, Rio Grande, RS, Brazil \\ 3 Universidade Estadual de Ponta Grossa, Departamento de Biologia Geral. CEP 84030-000, Ponta Grossa, PR, Brazil \\ * Corresponding author. E-mail: alfj__1@hotmail.com
}

\begin{abstract}
Four species of shell-less marine gastropods, collectively called "sea slugs", are newly recorded from outlets of estuarine systems, the Paranaguá estuarine complex and Guaratuba Bay, on the coast of Paraná state. These include a marine pulmonate slug, Onchidella indolens (Gould, 1852) (Eupulmonata: Systellommatophora: Onchidellidae); two species of sea hares, Bursatella leachii de Blainville, 1817 (Euthyneura: Sacoglossa: Aplysiidae) and Elysia serca Er. Marcus, 1955 (Euthyneura: Sacoglossa: Plakobranchidae); and one species of nudibranch, Spurilla braziliana MacFarland, 1909 (Nudipleura: Aeolidiidae). Egg mass shapes of E. serca and B. leachii are newly described.
\end{abstract}

Key words: egg masses, sea slugs, distribution gap, new records

Sea slugs are marine gastropods with no shell or the shell reduced and internal. They are hermaphrodites and may have their first stages of life in egg masses attached to a substratum or in larval forms of free living individuals (Schlesinger et. al. 2009; Matthews-Cascon et. al. 2011). Besides, the form and ornamentation of the egg masses are used to identify some heterobranch species (MatthewsCascon et. al. 2011).

Currently, approximately 200 sea slugs (Cephalaspidea; Systellommatophora; Sacoglossa; Nudibranchia) species are reported from Brazil (Rios 2009; DaCosta et al. 2010). Along the southern coast of Brazil, 45 species were recorded, including 21 from the state of Rio Grande do Sul, 31 from Santa Catarina and 4 from Paraná (Table 1). The perceived paucity of few sea slugs species from Paraná may be associated to the few studies on the group in the area or to a lack of favorable environmental conditions for their development.

The Paraná coast, located in southern Brazil, extends from the Ararapira village in the north $\left(25^{\circ} 12^{\prime} 44^{\prime \prime} \mathrm{S}, 48^{\circ} \mathrm{O} 1^{\prime} 15^{\prime \prime} \mathrm{W}\right)$ to Saí-Guaçu river mouth in the south $\left(25^{\circ} 5^{\prime} 38^{\prime \prime} \mathrm{S}, 48^{\circ} 35^{\prime} 26^{\prime \prime}\right.$ $\mathrm{W})$ and has two main estuaries: Paranaguá estuarine complex and Guaratuba Bay (Figure 1). This shore is characterized by several sandy beaches and few extensions of rocky coast (Noernberg et al. 2008).

Four individual of Onchidella indolens (Gould, 1852) were collected by hand in a rocky shore associated to macroalgae in the outlet of the Paranaguá estuarine complex, Mel Island, Encantada beach ( $25^{\circ} 33^{\prime} 47.77^{\prime \prime}$ S, 48 $18^{\circ} 05.74^{\prime \prime}$ W; 28 July 2010; collector: Iarema Carvalho). Also at the same outlet and associated with macroalgae were collected 3 individuals of Elysia serca Er. Marcus, 1955. Two individuals of Bursatella leachii de Blainville, 1817 were collected on the intertidal sand-mud flat at Baixio do Perigo (25⒉'24.05" S, 48 26'05.01"W; 4 August 2011; collector: Augusto Ferreira-Jr). Cross-fertilization between individuals of Bursatella leachii was observed in the field, with two to five individuals in sexual intercourse inside a depression (Figure 2). One specimen of Spurilla braziliana MacFarland, 1909 was collected at the outlet of Guaratuba Bay in an oyster culture located at Pinheiros River (25 49'56.02" S, 48 $34^{\prime} 46.78^{\prime \prime}$ W; 20 July 2011; collector: Augusto Ferreira-Jr) (Figure 2).

In the laboratory, the specimens of the four species were acclimatized in water with salinity varying from 20 to 30 psu. During this period, the specimens of Spurilla braziliana and Elysia serca spawned spiral egg masses (Figure 2). Egg mass shape was previously observed by Matthews-Cascon et al. (2011) for $S$. neapolitana, but is not previously known for E. serca. Egg masses of Bursatella leachii are a long, coiled, gelatinous string with each egg capsule with more than one larva (Figure 2). In the laboratory, Onchidella indolens and E. serca fed on macroalgae, as also reported by Rios (2009). Spurilla braziliana, preferred to feed on bryozoans and hydrozoans that were attached to oyster shells from which it was collected.

The new record of Elysia serca extends the known range of this species approximately $80 \mathrm{~km}$ south of the previous known distribution (Figure 1). The new records of Spurilla braziliana and Onchidella indolens in the coast of Paraná fill gaps in the known distributions of these two species, thus enabling a connection between the populations of the States of São Paulo and Santa Catarina, described earlier (Pimpão and Magalhães 2004; Rios 2009; Carmona et al. 2014). Recently 
Carmona et al. (2014) reported that the species of Spurilla present along the Brazilian coast is Spurilla braziliana and not Spurilla neapolitana (Delle Chiaje, 1841).

Heterobranchia from Paraná state are not well known, and this may be due to a lack of appropriate sampling in suitable habitats, both during larval and adult stages. The absence of studies focused in heterobranchs may explain the difference in occurrence of species in the state of Paraná, compared with the larger diversity of sea slugs reported from São Paulo and Santa Catarina. Further fieldwork on the coast of Paraná may add information about species still yet unknown from the state, as well as possibly increasing knowledge of the reproductive characteristics of heterobranch species in the region. The integration of morphological and molecular tools may also contribute to better identification of species and their distribution, as well as the interaction between populations of heterobranchs in southern Brazil.

\section{ACKNOWLEDGMENTS}

Financial support was provided by Conselho Nacional de Desenvolvimento Científico e Tecnológico (Cnpq). Special thanks are due to Hamilton Kirchner and Fazenda Marinha Ostra Viva for the help with equipment in the field work.

Table 1. Records of marine heterobranchs from the southern Brazil coast. PR: Paraná state; SC: Santa Catarina state; RS: Rio Grande do Sul state.

\begin{tabular}{|c|c|c|}
\hline Species & Location & References \\
\hline Acteocina bidentata (d'Orbigny, 1841) & PR, SC, RS & Morretes 1949; Garcia et al. 2008; Agudo-Padrón et al. 2009 \\
\hline Acteocina bullata (Kiener, 1834) & SC, RS & Wiggers and Magalhães 2003; Agudo-Padrón et al. 2009 \\
\hline Acteocina candei (d'Orbigny, 1841) & SC, RS & Morretes 1949; Garcia et al. 2008; Agudo-Padrón et al. 2009 \\
\hline Acteocina inconspicua (H. Adams, 1872) & SC, RS & Garcia et al. 2008; Agudo-Padrón et al. 2009 \\
\hline Acteon pelecais Ev. Marcus, 1972 & $\mathrm{SC}, \mathrm{RS}$ & Garcia et al. 2008; Agudo-Padrón et al. 2009; Rios 2009 \\
\hline Aeolidiella indica Bergh, 1888 & SC & Padula et al. 2011 \\
\hline Aplysia dactylomela Rang, 1828 & SC & Agudo-Padrón et al. 2009 \\
\hline Aplysia juliana Quoy \& Gaimard, 1823 & SC & Wiggers and Magalhães 2003; Agudo-Padrón et al. 2009 \\
\hline Aplysia fasciata Poiret, 1789 & SC & Morretes 1949; Garcia et al. 2008; Agudo-Padrón et al. 2009; Rios 2009 \\
\hline Armina muelleri (Ihering, 1886) & $\mathrm{SC}$ & Morretes 1949; Garcia et al. 2008; Agudo-Padrón et al. 2009; Rios 2009 \\
\hline Berghia rissodominguezi Muniain \& Ortea, 1999 & SC & Padula et al. 2011 \\
\hline Bulla striata Bruguìere, 1792 & $\mathrm{PR}, \mathrm{SC}$ & $\begin{array}{l}\text { Morretes 1949; Boehs et al. 2004; Garcia et al. 2008; Agudo-Padrón et al. 2009; Rios } \\
2009\end{array}$ \\
\hline Crenilabium birmani Simone, 2006 & RS & Rios 2009 \\
\hline Chromodoris paulomarcioi Domínguez, García \& Troncoso, 2006 & SC & Padula et al. 2011 \\
\hline Cylichna crispula Watson, 1883 & SC & Agudo-Padrón et al. 2009 \\
\hline Cylichna discus Watson, 1883 & RS & Garcia et al. 2008; Rios 2009 \\
\hline Cylichna verrillii Dall, 1889 & SC, RS & Wiggers and Magalhães 2003; Garcia et al. 2008; Agudo-Padrón et al. 2009 \\
\hline Doris verrucosa Linnaeus, 1758 & SC & Morretes 1949; Garcia et al. 2008; Agudo-Padrón et al. 2009; Rios 2009 \\
\hline Elysia serca Er. Marcus, 1955 & PR & This study \\
\hline Dendrodoris krebsii (Mörch, 1863) & SC & Ev. Marcus 1977; Agudo-Padrón et al. 2009; Rios 2009 \\
\hline Dondice occidentalis (Engel, 1925) & SC & Wiggers and Magalhães 2003; Agudo-Padrón et al. 2009 \\
\hline Etidoris ladislavii Ihering, 1886 & SC & Rios 2009 \\
\hline Flabellina engeli lucianae Dacosta, Cunha, Simone \& Schrödl, 2007 & SC & DaCosta et al. 2007 \\
\hline Glaucus atlanticus Forster, 1777 & RS & Garcia et al. 2008; Rios 2009 \\
\hline Haminocea elegans (Gray, 1825) & $\mathrm{PR}, \mathrm{SC}, \mathrm{RS}$ & Boehs et al. 2004; Garcia et al. 2008; Agudo-Padrón et al. 2009; Rios 2009 \\
\hline Mysouffa cumingii (A. Adams, 1855) & RS & Garcia et al. 2008; Agudo-Padrón et al. 2009; Rios 2009 \\
\hline Onchidella indolens (Gould, 1852) & PR, SC & This study; Agudo-Padrón et al. 2009; Rios 2009 \\
\hline Philine alba Mattox, 1958 & RS & Garcia et al. 2008; Rios 2009 \\
\hline Philine falklandica Powell, 1951 & RS & Garcia et al. 2008; Rios 2009 \\
\hline Philine mera Er. Marcus \& Ev. Marcus, 1969 & RS & Garcia et al. 2008; Rios 2009 \\
\hline Polycera aurisula Er. Marcus, 1957 & SC & Agudo-Padrón et al. 2009 \\
\hline Pleurobranchus areolatus Morch, 1863 & SC & Wiggers and Magalhães 2003; Agudo-Padrón et al. 2009; Rios 2009 \\
\hline Pleurobranchus inconspícua Bergh, 1897 & RS & Garcia et al. 2008; Rios 2009 \\
\hline Scaphander nobilis Verrill, 1884 & RS & Garcia et al. 2008 \\
\hline Scaphander watsoni Dall, 1881 & RS & Garcia et al. 2008 \\
\hline Spurilla gabriellae Vannucci, 1952 & PR & Vanucci, 1952; Morretes 1954 \\
\hline Spurilla braziliana Macfarland, 1909 & PR, SC & This study; Pimpão and Magalhães 2004; Agudo-Padrón et al. 2009; Rios 2009 \\
\hline Volvulella paupercula (Watson, 1883) & RS & Garcia et al. 2008; Rios 2009 \\
\hline Volvulella persimilis (Mörch, 1875) & RS & Garcia et al. 2008; Rios 2009 \\
\hline Tambja stegosauriformis Pola, Cervera \& Gosliner, 2005 & SC & Padula et al. 2011 \\
\hline Thordisa ladislavii (Ihering, 1886) & SC & Morretes 1949; Rios 2009 \\
\hline Tritonia eriosi Ev. Marcus, 1983 & RS & Garcia et al. 2008; Rios 2009 \\
\hline
\end{tabular}




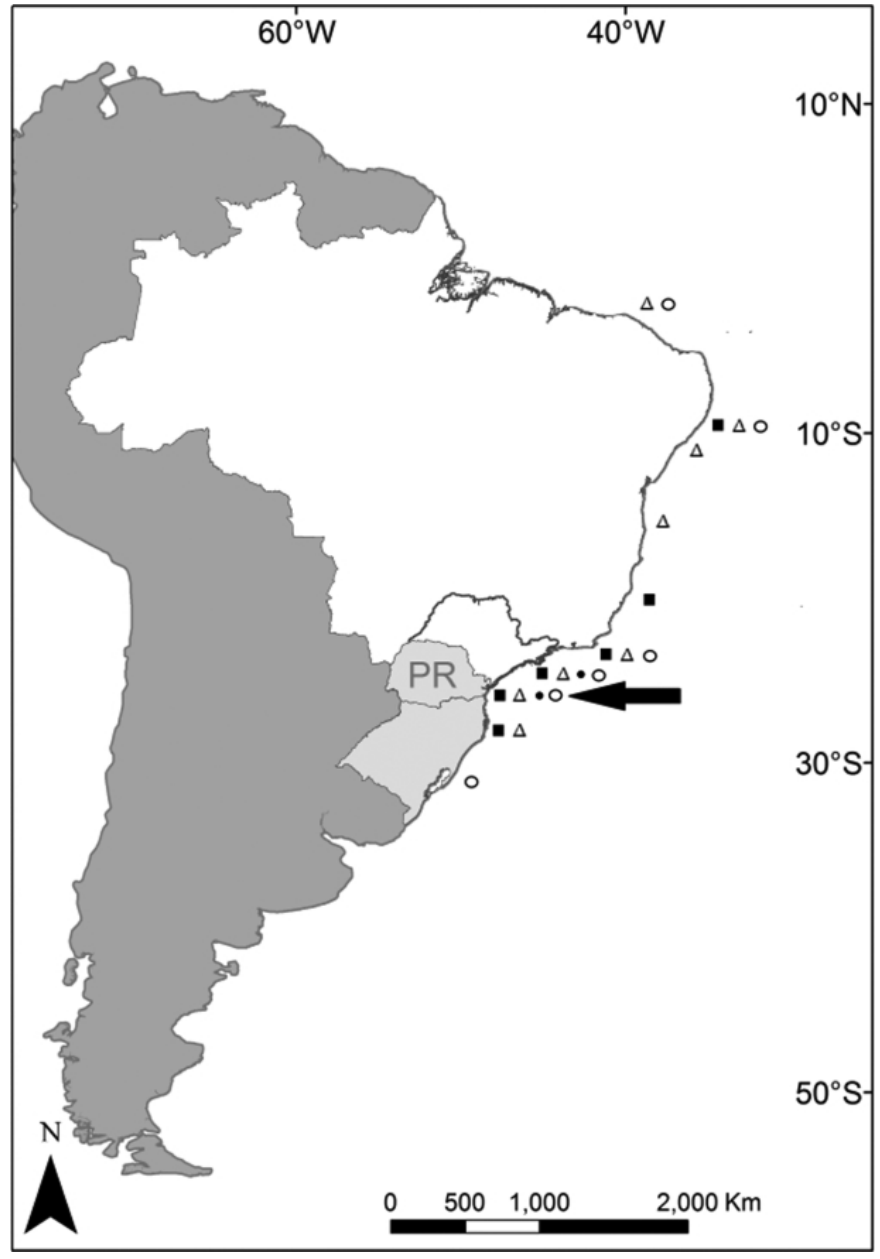

Figure 1. Geographic distribution of Onchidella indolens $(\mathbf{-})$, Spurilla braziliana $(\Delta)$, Bursatella leachii $(0)$ and Elysia serca $(\bullet)$, with indication of the news records from Paraná $(\mathrm{PR})$ state $(\longleftarrow)$. Light grey indicates southern Brazil.

\section{LITERATURE CITED}

Agudo-Padrón, A.I., M.S. Bleicker and K. Saafeld. 2009. Recent marine molluscs of Santa Catarina State, SC, southern Brazil region: A comprehensive synthesis and check list. VISAYA Net 3: 1-17.

Boehs, G., T.M. Absher and A. da Cruz-Kaled. 2004. Composition and distribution of benthic molluscs on intertidal flats of Paranaguá Bay (Paraná, Brazil). Scientia Marina 68(4): 537-543.

Carmona, L., Lei, B. R., Pola, M., Gosliner, T. M., Valdés, Á., and Cervera, J. L. 2014. Untangling the Spurilla neapolitana (Delle Chiaje, 1841) species complex: A review of the genus Spurilla Bergh, 1864 (Mollusca: Nudibranchia: Aeolidiidae). Zoological Journal of the Linnean Society, 170(1): 132-154 (doi: 10.1111/zoj.12098).

DaCosta, S., V. Padula and M. Schrödl. 2010. A new species of
Hypselodoris and a redescription of Hypselodoris picta lajensis (Nudibranchia: Chromodorididae) from Brazil. The Veliger 51(1): 15-25 (http://biodiversityheritagelibrary.org/page/42497394).

Domínguez, M., F.J. García and J.S. Troncoso. 2006. Some aspects of the family Chromodorididae (Opisthobranchia: Nudibranchia) from Brazil, with description of a new species. Scientia Marina 70(4): 621-634 (doi: 10.3989/scimar.2006.70n4621).

García García, F.J., M.D. Alvaréz and J.S. Troncoso. 2008. Opistobranquios de Brasil: Descripción y Distribución de Opistobranquios del Litoral de Brasil y del Archipiélago Fernando de Noronha. Vigo, Spain: Feito, S.L. 225 pp.

Marcus, Ev. 1977. An annotated checklist of the western Atlantic warm water opisthobranchs. Journal of Molluscan Studies 4(1): 1-23 (http://mollus.oxfordjournals.org/content/43/supp4/1.extract).

Matthews-Cascon, H., C.A. Rocha-Barreira and C.A.O. Meirelles. 2011. Egg Masses of Some Brazilian Mollusks. Fortaleza, Ceará: Expressão Gráfica e Editora. 119 pp.

Morretes, F.L. 1949. Ensaio de Catálogo dos Moluscos do Brasil. Arquivos do Museu Paranaense 7(1): 2-216.

Morretes, F.L. 1954. Adenda e corrigenda ao ensaio de catálogo dos moluscos do Brasil. Arquivos do Museu Paranaense 10(1): 37-76.

Noernberg, M.A., R. Angelotti, G.A. Caldeira and A.F. Ribeiro De Sousa. 2008. Environmental sensitivity assessment of Paraná coast for oil spill. Brazilian Journal Aquatic Science and Technology 12(2): 49-59 (doi: 10.14210/bjast.v12n2.p49-59).

Padula, V., J. Bahia, C. Vargas and A. Lindner. 2011. Mollusca, Nudibranchia: New records and southward range extensions in Santa Catarina, southern Brazil. Check List 7(6): 8o6-808 (http:// www.checklist.org.br/getpdf?NGD111-11).

Pimpão, D.M. and A.R.M. Magalhães. 2004. Primeiro registro de Spurilla neapolitana (Gastropoda, Nudibranchia) no litoral catarinense, SC, Brasil. Biociências 12(2): 181-183.

Rios, E.C. 2009. Compendium of Brazilian Sea Shells. Rio Grande, RS: Editora Evangraf. 668 pp.

Schlesinger, A., R. Goldshmid, M.G. Hadfield, E. Kramarsky-Winter and Y. Loya. 2009. Laboratory culture of the aeolid nudibranch Spurilla neapolitana (Mollusca, Opisthobranchia): Life history aspects. Marine Biology 156(4): 753-761 (doi: 10.1007/soo227-009-1126-o).

Vannucci, M. 1952. Eolidina (Spurilla) gabriellae sp. n.(Gastropoda Nudibranchia) from the states of Paraná and São Paulo. Dusenia (Publicatio Periodica de Scientia Naturali) 3: 283-288.

Wiggers, F. and A.R.M. Magalhães. 2003. Novas ocorrências de moluscos no litoral de Santa Catarina, Brasil. Biotemas 16(1): 81-89 (https:// periodicos.ufsc.br/index.php/biotemas/article/view/22095/20040).

Authors' contribution statement: AF compiled the map, identified some species and edited the text; IC made photographs, identified some species and edited of the text; SC wrote and revised of the text; TA made species identifications and wrote and revised the text.

Received: August 2014

Accepted: November 2014

Editorial responsibility: Robert G. Forsyth 

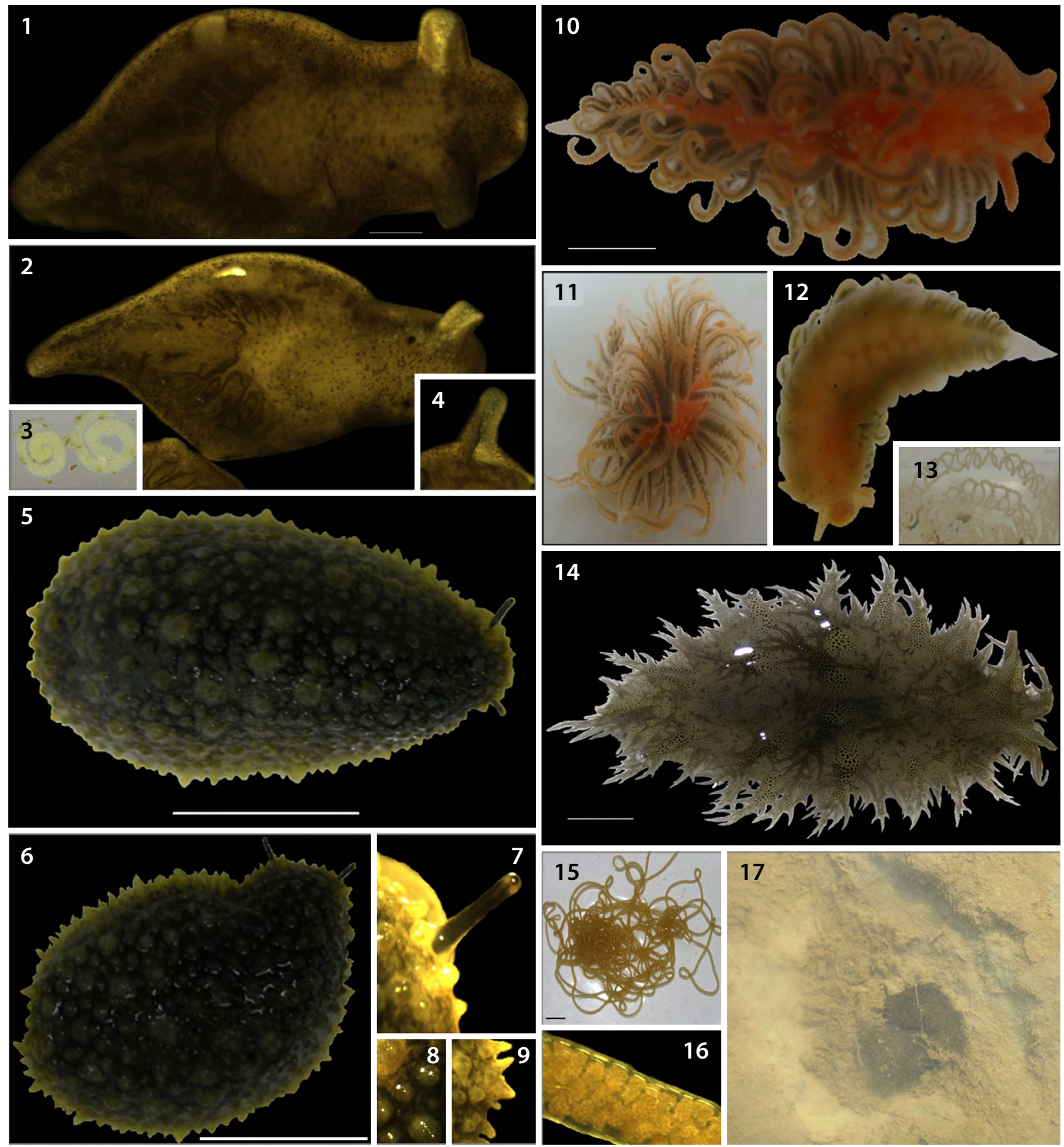

Figure 2. Heterobranchia from Paraná state, southern Brazil. 1-4: Elysia serca, Baixio do Perigo; 2, cross-fertilization; 3, egg mass; 4, rhinophore. 5-9: Onchidella indolens, Praia de Encantadas; 7, retractile tentacle bearing eyes; 8 and 9, skin projections. 10-13: Spurilla braziliana, Pinheiros River; 11, defense position; 12, ventral view and movement of spawning; 13, spawning; 14-17: Bursatella leachii, Baixio do Perigo; 15, spawning; 16, capsule and embryos; 17 , sexual intercourse in the field. Scale bars: $1,100 \mu \mathrm{m} ; 5,6,10 ; 14$ and $15,1 \mathrm{~cm}$. 